\title{
Correction: Kawasaki disease: a prospective population survey in the UK and Ireland from 2013 to 2015
}

Tulloh RMR, Mayon-White R, Harnden A, et al. Kawasaki disease: a prospective population survey in the UK and Ireland from 2013 to 2015. Arch Dis Child 2019;104:640-6. doi: 10.1136/archdischild-2018-315087.

The authors have requested the following acknowledgements statement should be added to their paper. 'This work was supported in part by the National Institute for Health Research Great Ormond Street Hospital Biomedical Research Centre'.

(C) Author(s) (or their employer(s)) 2020. No commercial re-use. See rights and permissions. Published by BMJ.

Arch Dis Child 2020;105:e5. doi:10.1136/archdischild-2018-315087corr1

D) Check for updates 